\title{
An Epidemiological Study of Fatal Aluminium Phosphide Poisoning At Rajkot
}

\author{
Dr. Sanjeevkumar Chaudhary ${ }^{1}$, Dr. S.G. Momin ${ }^{2}$ Dr. Dipak H. Vora ${ }^{3}$, Dr. \\ Pikesh Modi $^{4}$, Dr. Viral Chauhan ${ }^{5}$, Dr. Dipak Chotaliya ${ }^{5}$ \\ ${ }^{I} M D \&$ Assistant Professor, Forensic Medicine Department, Gitanjali Medical College, Udaipur, Rajasthan \\ ${ }^{2} \mathrm{MD} \&$ Assistant Professor, Forensic Medicine Department, B. J. Medical College, Ahmedabad \\ ${ }^{3}$ MD \& Assistant Professor, Forensic Medicine Department, P.D.U. Medical College, Rajkot \\ ${ }^{4}$ Tutor, Forensic Medicine Department, P.D.U. Medical College, Rajkot \\ ${ }^{5} 3 r d$ yr Resident Doctor, Forensic Medicine Department, P.D.U. Medical College, Rajkot
}

\begin{abstract}
Major occupation in Saurashtra region of Gujarat is farming with majority of population living in rural areas where the cases of accidental and suicidal poisoning are common and incidences are increasing day by day due to the use of pesticides for a wider variety of purposes. A detailed knowledge about the nature and magnitude of the poisoning cases in this particular area is not only important for early diagnosis and prompt treatment but also it may help to form policies to curb the access of the population to certain very toxic substances. The present study was undertaken in the department of Forensic Medicine at Rajkot (Gujarat) to know the pattern of fatal poisoning. Total 208 cases of death due to fatal poisoning were selected for this prospective study, which were brought to us for postmortem examination during the span of one year (From January 2007 to December 2007). Various aspects like relation with age, sex, kind of poison, hospitalization, caste and time between consumption and death were noted in 208 cases of poisoning. Our study revealed that most of the victims of fatal poisoning were Hindus, married males of middle socio-economic status who died due to self ingestion of some poison. Male: Female ratio was found to be 1.36:1. In the present study higher number of fatal poisonings episodes can be ascribed to pesticides but on the basis of WHO classification of poison, Aluminium Phosphide is most common fatal poison.
\end{abstract}

Keywords:- Aluminium Phosphide, Poisoning, Suicide.

\section{INTRODUCTION}

Poisoning is as old as our society. Of late, the incidence of poisoning cases is increasing steadily with each passing year. By definition, anything which when used internally or on the body surface in a dose or in repeated doses, if acts chemically and physiologically, causing disturbances of body functions and leads to disease or death is a poison. ${ }^{1}$ As per law, poison is a substance which when administered is injurious to health or life. ${ }^{2}$ Poisoning, both intentional or accidental, significantly contributes to mortality and morbidity throughout the world. According to W.H.O., 3 million acute poisoning cases with 220,000 deaths occur annually. ${ }^{3}$ Of these, $90 \%$ of fatal poisoning occurs in developing countries, particularly amongst the agricultural workers.

Acute poisoning forms one of the commonest causes of emergency hospital admissions. Pattern of poisoning in a region depends on variety of factors, such as availability of poisons, socioeconomic status of population, religious and cultural influence. The exact incidence of poisoning in India is uncertain due to lack of data at central level as most cases are not reported and as mortality data is a poor indicator of incidence of poisoning. It has been estimated that about 5-6 persons per lakhs of population die due to poisoning every year. ${ }^{4}$ Developing countries such as India and Sri Lanka have reported alarming rates of toxicity and deaths due to poisons. ${ }^{5}$ In United States, deaths due to poisoning number more than 775 per year. Most of the people who die from poisoning are adults and deaths often results from intentional rather than accidental exposure. ${ }^{6}$

Both homicidal and suicidal cases of poisoning are more common in India than in western countries, owing to easy availability of poison in the Indian markets. Insecticides and pesticides account for majority of these poisoning cases. More recently, Aluminium phosphide, because it is cheap, easily available, highly toxic, and has no antidote, has emerged as the most common suicidal agent ${ }^{7}$. The toxic effects of Aluminium phosphide are due to deadly phosphine gas liberated when it reacts with water or hydrochloric acid in the stomach. Organophosphorus compounds are other more common cause of insecticide poisoning in India. ${ }^{8}$

Aluminium Phosphide (ALP), a widely used solid fumigant, was declared as an ideal fumigant pesticide in 1973 for its effectiveness, easy to use and low cost properties. Available as tablets of 'Celphos', 
'Alphos' or 'Quickphos', each tablet weighing 3.0 gm liberates $1.0 \mathrm{gm}$ of phosphine gas $\left(\mathrm{PH}_{3}\right) . \mathrm{PH}_{3}$ being gaseous in nature diffuses uniformly throughout the stored grains, leaving non-toxic residues in the form of phosphite and hypophosphite of aluminium without affecting the food value of grains.

Epidemiology: Isolated cases of exposure to $\mathrm{PH}_{3}$ have been reported in the world literature ${ }^{9}$, but in India, a series of case reports and studies have appeared from different northern states ${ }^{\mathbf{1 0}}$. The poisoning has been steadily increasing and has achieved alarming epidemic proportion ${ }^{11}$. The poisoning involving primarily the youth is mostly suicidal, occasionally accidental and rarely homicidal ${ }^{\mathbf{1 2}}$. Recently, cases of poisoning with exposed compounds and its combined toxicity with ethyl alcohol have been reported ${ }^{13,14}$.

Mechanism of action: Initial studies carried out on different animals reported non-competitive binding of cytochrome oxidase by phosphine leading to valency change in the heme component of hemoglobin ${ }^{15,16}$, but later studies reported significant inhibition of catalase leading to accumulation of hydrogen peroxide ${ }^{17}$. More recent studies reported extra-mitochondrial release of hydrogen peroxide and liberation of oxygen free radicals ${ }^{\mathbf{1 8}}$ causing lipid peroxidation and protein denaturation of cell membrane leading to hypoxic cell damage. However, the exact mechanism of action of ALP is still unclear ${ }^{19}$.

Diagnosis of ALP poisoning is based on: (a) history of ingestion of the poison, (b) clinical manifestations, (c) foul or decaying fish like breath odour and (d) cardiac arrhythmias and metabolic acidosis. The confirmation of diagnosis is done by qualitative silver nitrate impregnated paper test for treatment purposes and by chemical analysis for medicolegal purposes.

\section{MATERIAL AND METHOD}

The present prospective study was conducted at Department of Forensic Medicine, P.D.U. Medical College Rajkot for period of one year from 1st January 2007 to 31st December 2007. All the fatal poisoning cases referred to P.D.U. Medical College and Hospital Rajkot was taken in to the study.

Out of total 2039 autopsies, 208 cases (10.02\%) of death due to poisoning were selected for the present study, which were referred to us for autopsy examination during the study period. Information about age, gender, residence, marital status and type of poison responsible in fatal poisoning cases were duly recorded. Information from relatives and accompanying police records were used to record the manner of poisoning, whether suicidal, accidental or homicidal. Detailed and complete post mortem examination was done by routine instruments and methods. The details of cases of poisoning were entered in the proforma and master chart of the cases of poisoning was prepared.

The exact types of poisons responsible in fatal cases were confirmed by cross checking with chemical analyzer's report whenever possible.

Data collected was entered into epidata version-3 and spread sheet so generated was validated for congruence. Data not found congruent were checked in the original proforma and corrections were made in both the master chart and spread sheet. Data thus validated was fed into statistica version-5.0, using statistica V generated group wise means for characteristics of the deceased persons. Comparison between the means of groups was made by ANOVA (Analysis of variant) module of the analytical packages. Differences were considered significant only when the Alfa-error was less than the level of $5 \%$. We have been represented in the table and text as $\mathrm{p}<0.05$. $^{\mathbf{2 0}}$

\section{OBSERVATIONS}

Out of total 2039 autopsies, 208 cases $(10.02 \%)$ of death due to poisoning were selected for the present study. Incidence of poisoning deaths was more in $3^{\text {rd }}$ decade $(32.79 \%)$ and $2^{\text {nd }}$ decade $(24.51 \%)$ of life as compared to both extremes of life. When age distribution of deaths are contrasted on the basis of gender then it become evident that male deaths are highest in the age group 21-30 years (35\%) but for female age group 11-20 years $(34.1 \%)$ reports the highest number of deaths. In the present study, death due to poisoning in male population was 1.36 times more in comparison to female population with male to female ratio of 1:0.73.

Maximum number of poisoning deaths observed in month of May (13\%) followed by month of March $(11 \%)$ but statistically no seasonal trend is observed in the total number of events and even when segregated by gender no trend was observed. Incidence of fatal poisoning was more in Hindus (89.90\%) as compared to Muslims (10.10\%) and in married victims (67.31\%).

A significant difference was observed between rural and urban areas on the basis of socio-economic status. In the urban areas middle socio-economic status people had higher odds of fatal event (44.71\%) whereas in rural areas lower socio-economic status people had higher odds of fatal event $(23.56 \%)$.

Pesticides constitute the largest group. It is the commonest available poison to the population. Aluminium phosphide was the second most common cause for fatal events.

Aluminium phosphide leads the lists of most killer poisons and accounts for 35.1 percent of deaths. Class Ib poisons are associated with second highest number of deaths followed by Class II and Class Ia. Only aluminium phosphide appears responsible for higher number of death in urban area. For all other poisons the urban rural gradient is not seen. 


\section{DISCUSSION}

Suicide is among the top 10 causes of deaths in India. The commonest mode of committing suicide in India is by the ingestion of poison. In the present study, deaths due to aluminium phosphide poisoning were $35.1 \%$ among all poisoning deaths. It has been observed that the Aluminium phosphide poisoning was mainly used for suicide.

In the present study, 21-30 years of age group showing higher incidence of poisoning accounted $32.79 \%$ which is similar with observations of other workers. ${ }^{\mathbf{2 1 - 2 4 , 2 7}}$ which can be explained by the fact that the persons of this young age group are suffering from stress of the modern life style, failure or less percentage in the exams, scolding from parents or teachers, failure in love, family problems etc. Change over from the concept of joint family to nuclear family has forced modern youth to face the problem of day to day living, both at home and outside, on their own without the much needed advice from the elders. When these problems and tensions become unbearable, ending one's life seems to be the only solution of them.

Sharma et $\mathrm{al}^{28}$ said that people in the extremes of the age groups i.e. below 15 years and above 60 years, were least prone to poisoning and the higher incidence of poisoning found in the age group of 15-30 years. Singh et $\mathbf{a l}^{\mathbf{2 6}}$ have also studied that younger age group is most susceptible to the lure of riches, the modern society's hard stick of success and frustrations caused by the inability to cope with the highly competitive, indifferent and materialistic society have resulted in increased poisoning in younger generations.

No significant seasonal trend is observed in the present study, which is also supported by the other authors. ${ }^{\mathbf{2 3 , 2 6}}$ In the present study, male groups (57.6\%) showing higher incidence of poisoning than the female groups (42.4\%). On comparison with authors ${ }^{22,24,25,27-31}$, our study showing similarity. Though all studies were conducted in different parts of India, male predominance was a common and constant feature in all, which suggests that male are more active in various social activities and customs and hence they are vulnerable from stress and tension.

In the present study, the incidence of poisoning is high in married people compared to that in

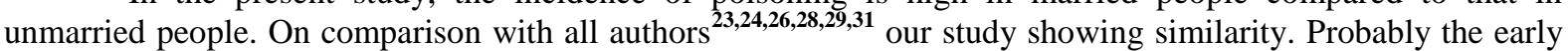
marriages in the rural community, familial responsibilities, social customs, limited sources of income, frustrations, dowry, family quarrels, mal-adjustments in marriage life, low level of education, infidelity, unemployment, etc are the important causes of more deaths in married people.

Maximum number of poisoning deaths occurred in the urban areas (64.9\%) as compared to the rural areas

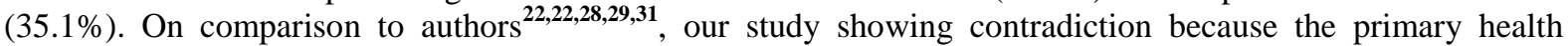
system is very strong in Gujarat state and all PHC and CHC functioning very well and also post-mortem examination held on every PHC and CHC. So the numbers of cases of poisoning deaths are not come for postmortem examination in our hospital. Now days due to globalization and urbanization, the people are migrating from the other district and other state which causes increase of population of the city, the urban people have lot of business failure and social problems so these factors contributing main role to commit suicide.

In the present study socio-economic status has different effect on the basis of area of residence. In rural deaths low socio-economic status confers higher odds of suicide whereas in urban areas medium socioeconomic status is having higher odds of suicide. Still, higher odds are observed for an unmarried lower socioeconomic person living in a joint family. Joint families system is more commonly observed in rural area in this series thus from the analysis we can assume in rural areas these can be the risk factors. However, poisoning is a random event and as most of the findings in our series is observational.

In the present study higher number of fatal poisonings episodes can be ascribed to pesticides but on the basis of WHO classification of poison, Aluminium Phosphide is most common fatal poison. The data presented in literature indicate that organophosphate pesticides are the predominant problem worldwide, being responsible for many cases of self-poisoning and the majority of deaths and a rural preponderance for pesticide poisoning are observed.

However, in the present study the rural urban division has been seen for Aluminium Phosphide, which appears more in urban area fatal events and no difference has been observed for pesticides.

\section{CONCLUSION}

The mortality due to ALP poisoning is very high and variable and depends upon a number of factors, the lack of antidote and the bad prognostic signs being the most prominent. The use of $\mathrm{MgSo}_{4}$ in reducing the cardiac arrhythmias and mortality is well documented and recommended. One most important factor which shall help to improve survival is providing preliminary medical-aid within $1 / 2$ to 1 hour of ALP intake at grass root levels. Other preventive measures are the caging of tablets in plastic packs with holes and spikes and more stringent restrictions on its supply in open market. The applicators of ALP must be licensed or working under the supervision of a licensed person. Improved education and enforcement of safety regulations would help to improve the frequency of the illness. Thus, the problem needs to be tackled by using multi-faceted approach in 
form of preventive measures, updating the management modalities at all levels and overall a study and research for an antidote which will prevent further loss of human lives as a result of poisoning.

Reducing deaths from self-poisoning require prevention strategies include treating the problems leading to suicidal behaviors involving pesticides; changing attitudes, knowledge, and beliefs about pesticides; controlling access to dangerous pesticides, including developing secure storage practices and improving the medical treatment of poisonings. More research is needed to better understand suicides involving pesticides in their cultural contexts and to evaluate the effectiveness of intervention programs, including assessment of possible substitution of methods.

In addition to all the above-mentioned measures of secondary prevention, an act of primary prevention is the need of the moment. Following measures can be of major public health utility:

Restricting the sale and storage of aluminium phosphide should be undertaken by stringent application of laws relating to pesticides.

Government should make a policy for giving purchasing card [license] to the users e.g. Farmers etc. of aluminium phosphide and other pesticides. The purchasing card [license] must be checked by the pesticides shop keeper before selling the pesticides. So aluminium phosphide and other pesticides will not be easily available to general population.

\section{ACKNOWLEDGEMENT}

Authors acknowledge the immense help received from the scholars whose articles are cited and included in references of this manuscript. The authors are also grateful to authors / editors / publishers of all those articles, journals and books from where the literature for this article has been reviewed and discussed.

\section{REFERENCES}

[1]. Nandy A. Forensic toxicology Principles of Forensic Medicine. 2nd Ed. pp. 438-54.

[2]. Glaister. Law relating to poisoning: Med Juris Toxicol. 1957; 10: 466-67.

[3]. WHO. Public health impact of pesticides used in agriculture. Geneva, WHO 1990.

[4]. Reddy KSN: The Essentials of Forensic Medicine and Toxicology, 29th Edition. K. Saguna Devi, Hyderabad, 2010; 449.

[5]. Senanayke NPH. Mortality due to poisoning in developing agricultural country over 20 years. Hum Exp Toxicol 1995; 14: 437-45.

[6]. Klaassen CD. Principles of toxicology and treatment of poisoning. Goodman \& Gilman. The Pharmacological Basis of Therapeutics. 10th International Ed, McGraw Hill, New York. PP 67-80.

[7]. Jay Ram KS. Death pills from pesticides. Nature 1991; 353: 177.

[8]. Parikh CK. Parikh's Textbook of Medical Jurisprudence, Forensic Medicine and Toxicology. $6^{\text {th }}$ Ed. CBS Publishers, New Delhi 2000; 10.41-10.49

[9]. Wilson R, Lovejoy FH, Jaeger RJ, et al. Acute phosphine poisoning aboard a grain freighter: epidemiological, clinical and pathological findings. JAMA 1980; 24: 148 - 150.

[10]. Saraswat PK, Gupta BP, Malhotra VK, et al. Prevalence of fatalities due to aluminium phosphide poisoning in Southern Rajasthan. J Forensic Med 1985; 2: 1 - 7.

[11]. Chug SN, Dushyant S, Arora B, Malhotra KC. Incidence and outcome of patients of aluminium phosphide poisoning in a hospital study. Ind J Med Res 1991; 94: 232 - 235

[12]. Singh S, Dilawar JB, Vashisht R, et al. Aluminium phosphide ingestion. BMJ 1985; 290 : 1110 1111

[13]. Chug SN, Arora V, Kau S, et al. Toxicity of exposed aluminium phosphide JAPI 1993; 41: 569.

[14]. Chug SN, Mittal A, Arora V, et al. Combined toxicity due to alcohol and aluminium phosphide JAPI 1993; $41: 679$.

[15]. Waxland J, Hayes Jr. Pesticides studies in man. $1^{\text {st }}$ Ed. William and Wilkins London, 1982; p 133.

[16]. Chertuka W, Kashi KP, Bond EP. The effect of phosphine on electron transport in mitochondria. Pest Biochem Physiol 1976; 6: 65 - 84.

[17]. Price NR, Moles KA, Hamphires OA. Phosphine toxicity and catalase activity in susceptible and resistant strains of lesser grain borer. Comp Biochem Physiol 1982; 73: 411 - 415.

[18]. Bolter CJ, Chertuka W. Extra-mitochondrial release of $\mathrm{H}_{2} \mathrm{O}_{2}$ from insect, mouse liver mitochondria using respiratory inhibitor phosphine, myxothiazole and antimycin and special analysis of inhibited cytochrome. Arch Biochem Biophy 1989; 278: 73.

[19]. Chug SN, Arora V, Sharma A, Chug K. Free radical scavengers and lipid peroxidation in acute aluminium phosphide poisoning IJMR. 1996; 104: 190

[20]. Methods of Statistics (Mahajan). ANOVA Methods For correlation and regression.Vol.2

[21]. Aggarwal N.K. and Aggarwal B.B.L. (1998) Trends of poisoning in Delhi, Journal of Indian Academy of Forensic Medicine, Vol-20, No-2, pp.32-36. 
[22]. Dalal J.S., Gorea R.K., Aggarwal A.K., Thind A.S. and Sandhu S.S. (1998). Poisoning Trends- a post mortem study, Journal of Indian Academy of Forensic Medicine, Vol-20, No-2, pp.27-31.

[23]. Dhattarwal S.K. and Dalal S.S. Profile of Deaths Due to Poisoning in Rohtak, Haryana in the year 1995, Journal of Forensic Medicine and Toxicology, Vol-XIV, No.1, pp.51.

[24]. Gargi J., Rai H., Chanana A., Raj G., Sharma G. and Bagga I.J.S. (2003) Current Trends of Poisoning - A Hospital Profile, Journal of Punjab Academy of Forensic Medicine And Toxicology, Vol-3, pp. 41-45.

[25]. Kapila P., Sekhon H.S. and Mishra V.K. (2003) Study of poisoning deaths in and around Shimla, Internet Indian Journal of Forensic Medicine and Toxicology, Vol-1, No-2.

[26]. Shingh K., Oberoi S.S. and Bhullar D.S. (2003) Poisoning Trends in the Malwa Region of Punjab, Journal of Punjab Academy of Forensic Medicine And Toxicology, Vol-3, No. 26-29.

[27]. Murari A. and Sharma G.K. (2000) A comparative study of poisoning cases autopsied in LHMC New Delhi and Jipmer, Pondicherry, Journal of Forensic Medicine and Toxicology, Vol-19, No-1, JanJune, pp.18-20.

[28]. Sharma B.R., Dasari H., Sharma V. and Vij K. (2000) The epidemiology of poisoning - An Indian view point, Journal of Forensic Medicine and Toxicology, Vol-19, No-2, July-December, pp. 5-11.

[29]. Shingh V.P., Sharma B.R., Dasari H. and Krishan V. (2004) A ten year study of poisoning cases in a tertiary care hospital, Internet Indian Journal of Forensic Medicine and Toxicology, Vol-1, No-2.

[30]. Zine K.U., Mohanty A.C. (1998) Pattern of acute poisoning at Indira Gandhi Medical college and hospital, Nagpur, Journal of Indian Academy of Forensic Medicine, Vol-20, No-2, pp.37-39.

[31]. Dhattarwal S.K. and Harman singh (2001) Profile of death due to poisoning in Rohtak, Haryana, Journal of Forensic Medicine and Toxicology, Vol-18, No-2, July-Dec. pp.28-29.

Table-1

Age \& Sex Wise Distribution of Poisoning

\begin{tabular}{|c|c|c||c|}
\hline $\begin{array}{c}\text { Age Group } \\
\text { (years) }\end{array}$ & $\begin{array}{c}\text { Numbers } \\
\text { of Male } \\
(\boldsymbol{\%})\end{array}$ & $\begin{array}{c}\text { Numbers } \\
\text { of Female } \\
(\boldsymbol{\%})\end{array}$ & $\begin{array}{c}\text { Total } \\
(\boldsymbol{\%})\end{array}$ \\
\hline Less than 10 & $1(0.8)$ & $1(1.1)$ & $2(1)$ \\
\hline 11 to 20 & $21(17.5)$ & $\mathbf{3 0}(\mathbf{3 4 . 1})$ & $51(24.5)$ \\
\hline 21 to 30 & $\mathbf{4 2 ( 3 5 )}$ & $26(29.6)$ & $\mathbf{6 8}(\mathbf{3 2 . 7})$ \\
\hline 31 to 40 & $23(19.2)$ & $12(13.6)$ & $35(16.8)$ \\
\hline 41 to 50 & $23(19.2)$ & $12(13.6)$ & $35(16.8)$ \\
\hline 51 to 60 & $6(5)$ & $5(5.8)$ & $11(5.3)$ \\
\hline 61 to 70 & $4(3.3)$ & $1(1.1)$ & $5(2.4)$ \\
\hline 71 to 80 & $0(0)$ & $1(1.1)$ & $1(0.5)$ \\
\hline Total & $\mathbf{1 2 0}(\mathbf{5 7 . 6 9})$ & $\mathbf{8 8 ( 4 2 . 3 1 )}$ & $\mathbf{2 0 8 ( 1 0 0 )}$ \\
\hline
\end{tabular}

Table-2

Month \& Sex Wise Distribution of Poisoning

\begin{tabular}{|c|c|c|c|}
\hline $\begin{array}{c}\text { Month of } \\
\text { Fatal } \\
\text { Poisoning }\end{array}$ & $\begin{array}{c}\text { Numbers of } \\
\text { Female (\%) }\end{array}$ & $\begin{array}{c}\text { Numbers of } \\
\text { Male (\%) }\end{array}$ & $\begin{array}{c}\text { Total } \\
(\%)\end{array}$ \\
\hline January & $5(6)$ & $9(8)$ & $14(7)$ \\
\hline February & $2(2)$ & $8(7)$ & $10(5)$ \\
\hline March & $10(11)$ & $13(11)$ & $23(11)$ \\
\hline April & $7(8)$ & $6(5)$ & $13(6)$ \\
\hline May & $\mathbf{1 4 ( 1 6 )}$ & $13(11)$ & $\mathbf{2 7 ( 1 3 )}$ \\
\hline June & $5(6)$ & $\mathbf{1 5 ( 1 3 )}$ & $20(10)$ \\
\hline July & $10(11)$ & $6(5)$ & $16(8)$ \\
\hline
\end{tabular}

\begin{tabular}{|c|c|c|c|}
\hline August & $10(11)$ & $9(8)$ & $19(9)$ \\
\hline September & $8(9)$ & $11(9)$ & $19(9)$ \\
\hline October & $6(7)$ & $\mathbf{1 5}(\mathbf{1 3})$ & $21(10)$ \\
\hline November & $6(7)$ & $6(5)$ & $12(6)$ \\
\hline December & $5(6)$ & $9(8)$ & $14(7)$ \\
\hline Total & $\mathbf{8 8 ( 4 2 . 3 )}$ & $\mathbf{1 2 0}(\mathbf{5 7 . 7})$ & $\mathbf{2 0 8}$ \\
\hline
\end{tabular}

Table-3

Religion and Marital Status Wise Distribution of Poisoning

\begin{tabular}{|c|c|c|c|c|}
\hline $\begin{array}{c}\text { Marital } \\
\text { status }\end{array}$ & Hindu & Muslim & Sikh & Total \\
\hline Unmarried & 66 & 02 & 0 & 68 \\
\hline Married & 121 & 19 & 0 & $\mathbf{1 4 0}$ \\
\hline Total & $\mathbf{1 8 7}$ & 21 & $\mathbf{0}$ & 208 \\
\hline
\end{tabular}

Table-4

Socio-Economic Status \& Area Wise Distribution of Poisoning

\begin{tabular}{|c|c|c|c|}
\hline $\begin{array}{c}\text { Socioeconomic } \\
\text { Status }\end{array}$ & $\begin{array}{c}\text { Rural } \\
\text { Area }\end{array}$ & $\begin{array}{c}\text { Urban } \\
\text { Area }\end{array}$ & Total \\
\hline Lower & 49 & 42 & $\mathbf{9 1}$ \\
\hline Middle & 24 & 93 & $\mathbf{1 1 7}$ \\
\hline Total & $\mathbf{7 3}$ & $\mathbf{1 3 5}$ & $\mathbf{2 0 8}$ \\
\hline
\end{tabular}


IOSR Journal of Pharmacy

e-ISSN: 2250-3013, p-ISSN: 2319-4219, www.iosrphr.org

Vol. 3, Issue 1, Jan.-Feb 2013, PP. 17-23

Table-5 The table shown below gives the presumptive diagnosis of poisoning either on post-mortem finding or confirmed history of poisoning.

\begin{tabular}{|c|c|c|c|c|}
\hline \multirow{2}{*}{\begin{tabular}{|c|} 
Poison \\
presumptive
\end{tabular}} & \multirow{2}{*}{ Occupation } & \multicolumn{3}{|c|}{ AREA } \\
\hline & & Rural & Urban & Totals \\
\hline \multirow{8}{*}{$\begin{array}{c}\text { Pesticide } \\
(50.9 \%)\end{array}$} & No work & 2 & 3 & 5 \\
\hline & Farmer & 17 & 0 & 17 \\
\hline & Business & 1 & 18 & 19 \\
\hline & Worker & 12 & 10 & 22 \\
\hline & Student & 5 & 14 & 19 \\
\hline & House Wife & 10 & 11 & 21 \\
\hline & Service & 0 & 3 & 3 \\
\hline & Total & 47 & 59 & 106 \\
\hline \multirow{8}{*}{$\begin{array}{c}\text { Aluminium } \\
\text { phosphide } \\
(35.1 \%)\end{array}$} & No work & 3 & 3 & 6 \\
\hline & Farmer & 8 & 0 & 8 \\
\hline & Business & 0 & 10 & 10 \\
\hline & Worker & 1 & 11 & 12 \\
\hline & Student & 1 & 10 & 11 \\
\hline & House Wife & 6 & 17 & 23 \\
\hline & Service & 0 & 3 & 3 \\
\hline & Total & 19 & 54 & 73 \\
\hline \multirow{8}{*}{$\begin{array}{c}\text { History of } \\
\text { unknown } \\
\text { poison } \\
(10.1 \%)\end{array}$} & No work & 1 & 1 & 2 \\
\hline & Farmer & 0 & 1 & 1 \\
\hline & Business & 0 & 8 & 8 \\
\hline & Worker & 0 & 2 & 2 \\
\hline & Student & 1 & 1 & 2 \\
\hline & House Wife & 2 & 4 & 6 \\
\hline & Service & 0 & 0 & 0 \\
\hline & Total & 4 & 17 & 21 \\
\hline \multirow{9}{*}{ Acid $(3.9 \%)$} & No work & 0 & 1 & 1 \\
\hline & Farmer & 0 & 0 & 0 \\
\hline & Business & 0 & 0 & 0 \\
\hline & Worker & 0 & 0 & 0 \\
\hline & Student & 0 & 2 & 2 \\
\hline & House Wife & 2 & 3 & 5 \\
\hline & Service & 0 & 0 & 0 \\
\hline & Total & 2 & 5 & 8 \\
\hline & Column & 73 & 135 & 208 \\
\hline
\end{tabular}


Table-6 : The table contrasts confirmed agent of poisoning on the basis of the area of residence of the deceased.

\begin{tabular}{|c|c|c|c|c|}
\hline $\begin{array}{c}\text { Poison type (Lab } \\
\text { report) }\end{array}$ & Rural & Urban & Total & $\begin{array}{c}\text { WHO } \\
\text { Class } \\
\text { of Poison }\end{array}$ \\
\hline $\begin{array}{l}\text { ALUMINIUM } \\
\text { PHOSPHIDE }\end{array}$ & 20 & 53 & 73 & $\begin{array}{c}\text { Not } \\
\text { classified } \\
\text { Highly } \\
\text { hazardous } \\
\text { (WHO) }\end{array}$ \\
\hline METHYL & 6 & 10 & 16 & Ia \\
\hline PHOSPHAMIDON & 3 & 2 & 5 & $\mathrm{Ia}$ \\
\hline PARATHION (OP) & 1 & 0 & 1 & Ia \\
\hline Total Ia (OP) & 10 & 12 & 22 & \\
\hline DICHLORVAS (OP) & 3 & 1 & 4 & $\mathrm{Ib}$ \\
\hline MONOCROTOPHOS & 13 & 12 & 25 & $\mathrm{Ib}$ \\
\hline Total Ib (OP) & 16 & 13 & 29 & \\
\hline CHLORIPYRIPHOS & 1 & 1 & 2 & II \\
\hline QUINALPHOS (OP) & 4 & 7 & 11 & II \\
\hline DIAMETHIOATE & 6 & 4 & 10 & II \\
\hline ETHION (OP) & 1 & 0 & 1 & II \\
\hline Total II (OP) & 12 & 12 & 24 & \\
\hline PYRITHEROIDS (P) & 0 & 1 & 1 & II \\
\hline FENWALRATE $(\mathrm{P})$ & 0 & 1 & 1 & II \\
\hline PROPOXUR (C) & 0 & 4 & 4 & II \\
\hline ENDOSULFAN (OC) & 4 & 9 & 13 & II \\
\hline $\mathrm{HCL}$ & 2 & 3 & 5 & Not \\
\hline MALATHION (OP) & 4 & 8 & 12 & III \\
\hline Pending report & 0 & 7 & 7 & \\
\hline Not Detected & 5 & 12 & 17 & \\
\hline Column Total & 73 & 135 & 208 & \\
\hline
\end{tabular}

